\title{
Economical Performances and Cholesterol Profiles due to the Incorporation of Salvinia molesta in the Diets of Kampong Chicken
}

\author{
A. Setiadia,*, S. I. Santoso a , B. M. Setiawan ${ }^{a}$, S. Nurfadillah ${ }^{a}$, H. Sasana ${ }^{b}$, K. Prayoga $^{a}$, \& S. Susanti $^{c}$ \\ ${ }^{a}$ Agribusiness Program, Faculty of Animal and Agricultural Sciences, Diponegoro University \\ bFaculty of Economics and Business, Diponegoro University \\ ${ }^{\mathrm{c} F o o d}$ Technology Program, Faculty of Animal and Agricultural Sciences, Diponegoro University \\ Jalan Prof. Soedarto, Tembalang, Semarang, Central Java 50275, Indonesia \\ *Corresponding author: agus_setiadi2006@yahoo.co.id \\ (Received 22-04-2020; Revised 07-07-2020; Accepted 15-07-2020)
}

\begin{abstract}
This study aimed to perform an assessment of economic performance and meat cholesterol profiles of Kampong chickens fed diets with the increasing levels of Salvinia molesta. One hundred male Kampong chickens were divided into 4 treatments containing $0 \%$ (T0), 6\% (T1), 12\% (T2), and 18\% (T3) of S. molesta leaf (SML) in the diet. Then, an economic analysis was performed by calculating revenue, feed cost, and income over feed cost (IOFC). Investment analysis was computed when the farmers raised 1000 heads of Kampong Chicken utilized SML in the feed. NPV, PP, and B/C ratio were calculated for each treatment. The performance of the Kampong chickens fed the diet with SML content of $18 \%$ gave the best feed consumption, the final weight, and FCR. Kampong chickens fed diet with SML content of $18 \%$ gave the best IOFC. In the investment analysis, the Kampong chicken fed diet contained 18\% SML gave the best NPV, PP, and B/C ratio. Regression analysis was conducted on the level of SML in the diet of kampong chicken on some parameters. Kampong chicken fed diet contained SML had significantly higher HDL and lower LDL concentrations. The optimum inclusion level of SML leading to a reduced feed cost and increased IOFC, as well as feasibility, was $18 \%$. Based on the study, utilization of SML up to $18 \%$ in the diet of kampong chicken technically and economically gave the best performances.
\end{abstract}

Keywords: cholesterol profile; economic performance; Kampong chicken; Salvinia molesta

\section{INTRODUCTION}

Kampong chicken has become an alternative source of animal-based protein, which is increasingly in demand by the public. The awareness of the healthfood consumption pattern is the main reason for many people to switch from broiler to Kampong chicken's meats consumption. Kampong chicken's meat is believed to be healthier and tastier than broiler's meat. The price of Kampong chicken's meat in the market is much higher than that of broiler chicken. This provides the industry with an important advantage and is the reason for the promise of the industry.

Kampong chickens that are mostly raised by every household in the village have the potential to increase income and generate employment, as well as to contribute to the national supply of meat. The constraint is that their low productivity needs to improve through the implementation of appropriate technology and development programs that are economically profitable, socially acceptable, and environmentally sound (Wilson et al., 2018).

Feed ingredients are the most important aspect of the rearing of poultry since it is primarily responsible for the growth response (Akpaeti \& Agom, 2018;
Amerah et al., 2013). However, in Indonesia, almost all the main ingredients of chicken feed are imported from other countries. This leads to the higher and less competitive cost of chicken production in Indonesia compared to the other countries.

Feed ingredients that compete with food needs cause an increase in price. This condition requires us to look for alternatives of animal feed that are cheap and locally available to maintain the stability of future poultry production (FAO, 2010; Nampoothiri, 2017). Both the producers and researchers should identify alternative feed resources, especially the ones which are naturally and abundantly available in the environment, relatively cheap to produce, eco-friendly, and pose less competition with human nutrition and other industrial applications. The need for alternative feeds with these criteria has encouraged the utilization of Salvinia molesta (Gena et al., 2014; Mukherjee et al., 2010). S. molesta is a water weed that is easily found in the rice field, lake, and pond. Leterme et al. (2009 \& 2010) have studied the utilization of SML in the diet, and they found SML could be effectively utilized as an animal feed. Until now in Indonesia, S. molesta has not been commonly used as an alternative feed material for native chickens. Dwiloka et al. (2015) stated that S. molesta has the poten- 
tial to be utilized as a growth promotor of low-cost duck production.

S. molesta has the potential as a cheap local ingredient containing $111.24 \mathrm{mg} / \mathrm{kg} \beta$-carotene, $3.20 \mathrm{mg} / 30$ g vitamin C, $15.9 \%$ crude protein, $17.21 \%$ crude fiber, metabolic energy of 2,200 kcal/ $\mathrm{kg}$, and hemicellulose (Anderson et al., 2011; Kurniawan et al., 2010). SM leaf has been used as feed (Santoso et al., 2017; Santoso et al., 2016; Dwiloka et al., 2015; Leterme et al., 2010). SM leaf has been studied or even used as feeds for sows, broilers, and ducks, but has never been studied in Kampong chicken. Therefore, this research aimed to perform an assessment of economic performance and cholesterol profile of the Kampong chicken fed diet with various levels of S. molesta.

\section{MATERIALS AND METHODS}

\section{Material and Sample Preparation}

The experiment was approved by the animal ethics committee of Faculty of Animal and Agricultural Science, Diponegoro University (No. 3116/UN7.5.5/ KP2018, 27 April 2018). S. molesta was taken from Rawa Pening Lake, Semarang Regency, Central Java, Indonesia. S. molesta was harvested from Rawa Pening Lake, then was sundried for 3 days, and was grinded into a powder form. It cost IDR 300,000 to produce 120 $\mathrm{kg}$ of SML as feed material in a single batch. These costs

Table 1. Diet in starter period

\begin{tabular}{|c|c|c|c|c|}
\hline \multirow{2}{*}{ Ingredients } & \multicolumn{4}{|c|}{ Treatment diets } \\
\hline & T0 & $\mathrm{T} 1$ & $\mathrm{~T} 2$ & T3 \\
\hline \multicolumn{5}{|l|}{ Percentage (\%) } \\
\hline Corn & 52.1 & 52.3 & 51.0 & 51.8 \\
\hline SM leaf meal & 21.3 & 17.0 & 14.0 & 10.8 \\
\hline Rice bran & 16.8 & 15.9 & 15.1 & 11.8 \\
\hline Salvinia molesta & 0.0 & 6.0 & 12.0 & 18.0 \\
\hline Fish meal & 5.0 & 5.0 & 5.0 & 5.0 \\
\hline Coconut oil & 1.2 & 1.2 & 1.3 & 1.3 \\
\hline $\mathrm{CaCO}_{3}$ & 0.8 & 0.7 & 0.4 & 0.4 \\
\hline Premix & 0.8 & 0.7 & 0.4 & 0.3 \\
\hline Methionine & 1.0 & 0.6 & 0.4 & 0.3 \\
\hline Lysine & 1.0 & 0.6 & 0.4 & 0.3 \\
\hline Total & 100.0 & 100.0 & 100.0 & 100.0 \\
\hline \multicolumn{5}{|l|}{ Nutrition analysis } \\
\hline Energy (kcal/kg) & 2900.71 & 2900.84 & 2900.31 & 2900.80 \\
\hline Crude protein $(\%)^{*}$ & 20.32 & 20.04 & 20.27 & 20.33 \\
\hline Fat $(\%)^{*}$ & 5.04 & 4.94 & 4.91 & 4.68 \\
\hline Crude fiber $(\%)^{*}$ & 6.22 & 8.36 & 10.57 & 12.10 \\
\hline Methionine $(\%)^{* *}$ & 1.26 & 0.97 & 0.87 & 0.85 \\
\hline Lysine (\%) & 1.55 & 1.42 & 1.47 & 1.61 \\
\hline $\mathrm{Ca}(\%)^{* *}$ & 1.24 & 1.77 & 2.10 & 2.73 \\
\hline $\mathrm{P}(\%)^{* *}$ & 0.72 & 1.05 & 1.39 & 1.70 \\
\hline
\end{tabular}

Note: ${ }^{*}=$ Proximate analysis was conducted in Faculty of Animal Science and Agriculture, Diponegoro University; ${ }^{* *}=$ Feed Ingredients Composition Table, Indonesian National Standard (SNI), 2017. Treatment diets containing $0 \%$ (T0), $6 \%$ (T1), $12 \%$ (T2), and 18\% (T3) of Salvinia molesta leaf (SML). consisted of labor costs and transportation costs so that the estimated cost of producing SML powder is IDR 2,500 per $\mathrm{kg}$.

\section{Research Procedure}

This study used a completely randomized design using 100 heads of male Kampong chickens. The kampong chickens with an initial weight of $42 \pm 3 \mathrm{~g}$ were divided into four groups consisting of five replicates and randomly assigned to one of the treatment diets containing $0 \%(\mathrm{~T} 0), 6 \%$ (T1), 12\% (T2), and 18\% (T3) $\mathrm{SML}$ in the ration. The experimental Kampong chickens were housed in battery cages with room temperature ranged from $23^{\circ} \mathrm{C}$ to $38^{\circ} \mathrm{C}$ with food and water provided ad libitum. Performance (live weight, body weight gain, feed consumption, and feed conversion ratio), cholesterol profile, feed cost, and feasibility were analyzed. The composition of diets during starter and finisher periods are shown in Table 1 and Table 2.

\section{Meat Cholesterol Content Determination}

The modified saponification process was used to measure the cholesterol content of meat. Each sample (approximately $2 \mathrm{~g}$ ) was saponified with $4 \mathrm{~mL}$ of potassium hydroxide (50\%) and $6 \mathrm{~mL}$ of ethanol $(95 \%)$, absolute, heated at $40^{\circ} \mathrm{C}$ to complete solubilization and then heated at $60^{\circ} \mathrm{C}$ for 10 minutes. An amount of $5 \mathrm{~mL}$

Table 2. Diet in finisher period

\begin{tabular}{|c|c|c|c|c|}
\hline \multirow{2}{*}{ Ingredients } & \multicolumn{4}{|c|}{ Treatment diets } \\
\hline & T0 & $\mathrm{T} 1$ & $\mathrm{~T} 2$ & T3 \\
\hline \multicolumn{5}{|l|}{ Percentage (\%) } \\
\hline Corn & 54.0 & 52.9 & 52.6 & 52.5 \\
\hline Soybean meal & 19.3 & 16.5 & 12.7 & 9.4 \\
\hline Rice bran & 17.7 & 17.6 & 16.4 & 14.6 \\
\hline SM leaf meal & 0.0 & 6.0 & 12.0 & 18.0 \\
\hline Fish meal & 4.0 & 3.5 & 3.5 & 3.5 \\
\hline Coconut oil & 1.2 & 1.1 & 1.2 & 1.0 \\
\hline $\mathrm{CaCO}_{3}$ & 1.0 & 0.7 & 0.4 & 0.2 \\
\hline Premix & 1.0 & 0.5 & 0.4 & 0.2 \\
\hline Methionine & 0.9 & 0.6 & 0.4 & 0.2 \\
\hline Lysine & 0.9 & 0.6 & 0.4 & 0.2 \\
\hline Total & 100.0 & 100.0 & 100.0 & 100.0 \\
\hline \multicolumn{5}{|l|}{ Nutrition analysis } \\
\hline Energy (kcal/kg) & 2902.62 & 2901.51 & 2901.97 & 2902.10 \\
\hline Crude protein $(\%)^{*}$ & 19.02 & 19.14 & 19.03 & 19.12 \\
\hline Fat $(\%)^{*}$ & 5.09 & 4.91 & 4.87 & 4.71 \\
\hline Crude fiber $(\%)^{*}$ & 6.31 & 8.68 & 10.75 & 12.68 \\
\hline Methionine $(\%)^{* *}$ & 1.14 & 0.94 & 0.84 & 0.73 \\
\hline Lysine $(\%)^{* *}$ & 1.42 & 1.39 & 1.44 & 1.49 \\
\hline $\mathrm{Ca}(\%)^{* *}$ & 1.36 & 1.65 & 1.98 & 2.41 \\
\hline $\mathrm{P}(\%)^{* *}$ & 0.68 & 1.02 & 1.35 & 1.68 \\
\hline
\end{tabular}

Note: *=Proximate analysis was conducted in Faculty of Animal Science and Agriculture, Diponegoro University; ${ }^{* *}=$ Feed Ingredients Composition Table, Indonesian National Standard (SNI), 2017. Treatment diets containing $0 \%$ (T0), 6\% (T1), 12\% (T2), and 18\% (T3) of Salvinia molesta leaf (SML). 
of water was added, so the samples were cooled. The non-saponifiable fraction was extracted three times using $10 \mathrm{~mL}$ of hexane. Aliquots of hexane extracts $(3 \mathrm{~mL})$ were dried under nitrogen flow. After saponification, the samples were analyzed by enzymatic methods. The extract was diluted in $0.2 \mathrm{~mL}$ of isopropyl alcohol and analyzed with an enzymatic kit (Merck® Diagnostica, Darmstadt, Germany) (Dwiloka et al., 2015).

\section{Data Analysis}

Feed consumption. Feed intake was measured by weighing the given diet subtracted by the unconsumed feed daily diet in grams during treatment per week (Rathod et al., 2019).

Feed intake $=($ total amount of feed consumed $) /$ week

Feed conversion ratio. Feed conversion ratio (FCR) was calculated by dividing the amount of feed consumed with body weight gain (Omasaki et al., 2017).

$\mathrm{FCR}=($ amount of feed consumed $) /($ body weight gain $)$

Feed cost. Feed cost was calculated from 4 to 10 weeks of age of experiment duration. Feed cost was obtained based on the feed price multiplied by the daily consumption then expressed in IDR/head/day (Chander et al., 2017). While feed price (IDR/kg) is obtained by multiplying the price of each ingredient, then multiplied by the amount of diet composition. The $S$. molesta price $(\mathrm{IDR} / \mathrm{kg}$ ) is obtained from the wages divided by the number of person-days (generated SM in the wet form then converted into the dry material) plus transportation and milling costs.

Income over feed cost. Income over feed cost came from the income minus feed and was expressed in IDR/head (Rawat et al., 2018).

$\mathrm{IOFC}=(\mathrm{BW} \times \mathrm{x}$ chicken price $/ \mathrm{kg}$ live $)-(\Sigma \mathrm{x}$ feed intake of feed cost $/ \mathrm{kg}$ ).

Feasibility analysis. Economic analysis was derived from dividing IOFC by the feed cost. The other costs were assumed by ceteris paribus. Economic analysis of the utilization of S. molesta in the feed of Kampong chicken was computed as feed price revenue, feed cost, and IOFC. The feasibility was computed to determine the possibility of kampong chicken business using $S$. molesta as a diet component. Investment analysis was computed when chicken farmers raised 1000 heads of Kampong chicken, such as Net Present Value (NPV), Payback Period (PP), and Benefit-Cost Ratio (B/C Ratio) (Paguia et al., 2014; Reyes et al., 2018).

Statistical analysis. Data were analyzed using the General Linear Model (GLM) of SPSS 16.0. Least Square Means (LSM) were calculated, and differences among treatment means were analyzed by Duncan Multiple Range Test (DMRT). Regression analysis was run to examine the relationship between the level of SML in the diet as an independent variable and feed consumption, final weight, FCR, total cholesterol, revenue, or IOFC as dependent variables. Statistical significances and tendencies were set at $\mathrm{p} \leq 0.05$ (Sudhakar et al., 2016).

\section{RESULTS}

Feed consumptions of Kampong chickens fed a diet with SML contents at the levels of $6 \%$ (T1), 12\% (T2), and $18 \%$ (T3) differed significantly from that of control Kampong chickens without SML supplementation on days 16-84. Feed consumptions of Kampong chickens fed a diet with SML contents of $6 \%$ (T1) and 12\% (T2) was higher than control Kampong chickens without SML supplementation (T0) and Kampong chickens fed diet supplemented with SML at the level of $18 \%$ (T3) on days 16-49. However, on days 50-84, feed consumptions of Kampong chickens fed diet with SML was higher (Table 3).

As were shown in Figure 1, feed consumptions of Kampong chickens fed diet supplemented with SML at the levels of $6 \%(\mathrm{~T} 1), 12 \%$ (T2), and $18 \%$ (T3) were greater than that of control Kampong chickens without SML supplementation (T0). The feed consumptions tended to be increased when the level of SML increased in the diet. Feed consumptions of Kampong chickens fed diet with 18\% SML (T3) had the highest value, but

Table 3. Performance of kampong chicken fed diet with various levels of Salvinia molesta

\begin{tabular}{|c|c|c|c|c|c|}
\hline \multirow{2}{*}{ Variables } & \multicolumn{5}{|c|}{ Treatment diets } \\
\hline & T0 & $\mathrm{T} 1$ & $\mathrm{~T} 2$ & T3 & p-Value \\
\hline \multicolumn{6}{|c|}{ Feed consumption (g) } \\
\hline 16-49 days & $1163.07 \pm 4.93^{\mathrm{a}}$ & $1357.60 \pm 15.35^{\mathrm{b}}$ & $1431.08 \pm 2.94^{b}$ & $1117.12 \pm 7.67 \mathrm{~b}$ & $<0.01$ \\
\hline 50-84 days & $1579.15 \pm 7.18^{\mathrm{a}}$ & $2014.78 \pm 4.09^{b}$ & $2096.57 \pm 5.43^{\mathrm{b}}$ & $2193.42 \pm 1.58^{\mathrm{b}}$ & $<0.01$ \\
\hline \multicolumn{6}{|l|}{ Weight (g) } \\
\hline 16-49 days & $542.60 \pm 63.52$ & $543.12 \pm 31.45$ & $476.55 \pm 99.16$ & $469.40 \pm 19.14$ & 0.07 \\
\hline 50-84 days & $738 \pm 1.29 a$ & $843 \pm 2.60^{b}$ & $819 \pm 1.69^{b}$ & $850 \pm 2.00^{\mathrm{b}}$ & $<0.01$ \\
\hline \multicolumn{6}{|l|}{ FCR $(\%)$} \\
\hline 16-49 days & $2.10 \pm 0.23^{a}$ & $2.50 \pm 0.16^{\mathrm{ab}}$ & $3.00 \pm 0.62^{b}$ & $2.38 \pm 0.10^{\mathrm{b}}$ & $<0.01$ \\
\hline 50-84 days & $2.14 \pm 0.01^{\mathrm{a}}$ & $2.39 \pm 0.008^{\mathrm{ab}}$ & $2.56 \pm 0.01^{\mathrm{b}}$ & $2.58 \pm 0.04^{b}$ & $<0.01$ \\
\hline Mortality (\%) & 0 & 0 & 0 & 0 & \\
\hline
\end{tabular}

Note: means in the same row with different superscripts differ significantly ( $\mathrm{p}<0.05)$. Treatment diets containing $0 \%(\mathrm{~T} 0), 6 \%(\mathrm{~T} 1), 12 \%(\mathrm{~T} 2)$, and $18 \%$ (T3) of Salvinia molesta leaf (SML). FCR= feed conversion ratio. 
it was not statistically different compared to those of Kampong chickens fed diet with SML concentrations of $6 \%$ (T1) and $12 \%$ (T2). The final weights of kampong chickens fed diets with SML concentrations of $6 \%$ (T1), $12 \%$ (T2), and $18 \%$ (T3) were also higher compared to that of Kampong chickens without SML supplementation (T0) (Figure 2). The results showed that Kampong chickens fed diet with 18\% SML (T3) had the highest feed consumptions and also with the highest final body weights.

As was shown in Figure 3, each FCR of Kampong chickens fed diet with SML percentages of 6\% (T1), $12 \%$ (T2), and 18\% (T3) were not statistically different but numerically higher than control Kampong chickens fed diet without SML supplementation (T0). FCRs of Kampong chickens fed diets with SML were higher than that of control Kampong chickens without SML on days 16-84. Kampong chickens fed diet with 18\% SML content (T3) gave the best weight during 50-84 days (Table 3). FCR was influenced by the total feed consumed and weight gain. Control Kampong chickens fed diet without SML supplementation (T0) gave the best FCR result. However, Kampong chickens fed diet with 18\% SML content (T3) did not have a significantly different FCR compared to Kampong chickens supplemented with SML at the level of $6 \%$ (T1) and $12 \%$ (T2).

Feed prices at the starter and finisher period tended to be decreased when the level of SML in the ration increased. Conversely, the feed cost, revenue, and IOFC increased with the addition of SML in the feed (Table

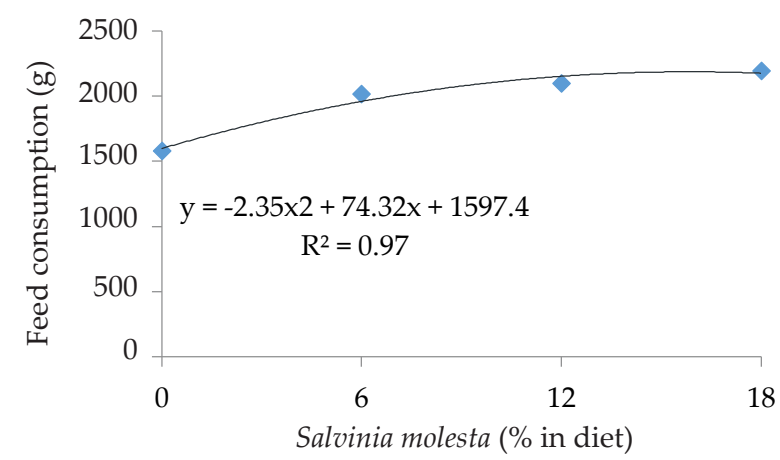

Figure 1. Feed consumption of kampong chickens fed diet with various levels of Salvinia molesta leaf (SML)

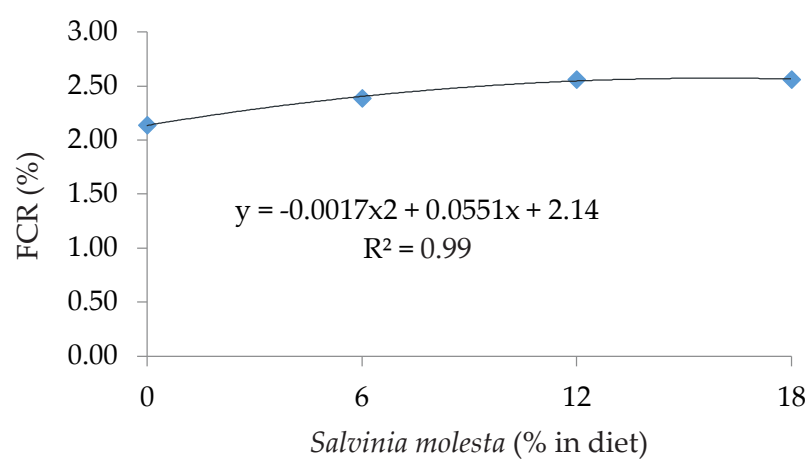

Figure 3. Feed conversion ratio of kampong chickens fed diet with various levels of Salvinia molesta leaf (SML)
4, Figure 4 and 5). Investment analysis showed that the utilization of SML leads to a higher NPV and B/C ratio and a shorter payback period (Table 5).

The cholesterol contents of meats of Kampong chicken were significantly different (Table 6, Figure 6). Kampong chickens fed diet with 18\% SML content (T3) had the lowest total meat cholesterol content $(\mathrm{p}<0.05)$ compared to Kampong chickens fed rations with SML contents of $0 \%$ (T0), $6 \%$ (T1), and 12\% (T2). However, HDL levels in the meat of Kampong chickens fed ration with SML level of 18\% (T3) were higher compared to Kampong chickens fed ration with SML levels of $0 \%$ (T0), 6\% (T1), and 12\% (T2). Meat LDL levels of Kampong chickens fed ration with SML concentration of $18 \%$ (T3) were the lowest compared to those of Kampong chickens fed rations with SML concentrations of $0 \%$ (T0), $6 \%$ (T1), and 12\% (T2). Kampong chickens fed ration with the SML concentration of $18 \%$ (T3) gave the best performance. Based on the meat cholesterol, HDL, and LDL concentrations, Kampong chickens fed ration with SML concentration of $18 \%$ (T3) gave the best performance.

\section{DISCUSSION}

Feed consumption tends to be increased with the increased level of SML in the rations, and Kampong chickens fed ration with SML concentration of 18\% (T3) have the highest feed consumption and also the highest final weight. The palatability of diet will influence feed

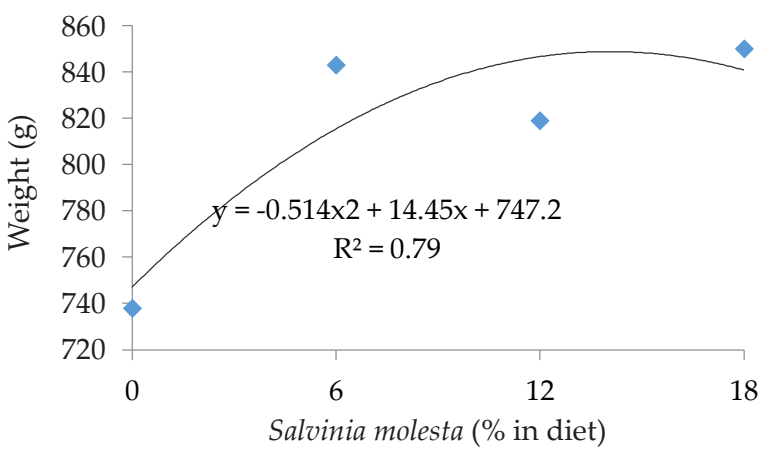

Figure 2. Final weight of kampong chicken fed diet with various levels of Salvinia molesta leaf (SML)

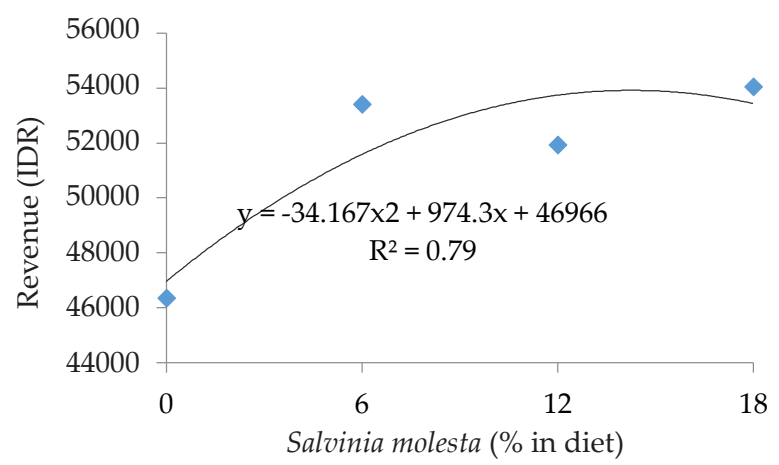

Figure 4. Revenue of kampong chicken fed diet with various levels of Salvinia molesta leaf (SML) 
Table 4. Economic analysis of kampong chickens fed diet with various levels of Salvinia molesta

\begin{tabular}{lrrrr}
\hline \multirow{2}{*}{ Items } & \multicolumn{4}{c}{ Treatment diets } \\
\cline { 2 - 5 } & \multicolumn{1}{c}{ T0 } & \multicolumn{1}{c}{ T1 } & \multicolumn{1}{c}{ T2 } & \multicolumn{1}{c}{ T3 } \\
\hline $\begin{array}{l}\text { Feed price at starter } \\
\text { period (IDR) }\end{array}$ & 6,776 & 5,970 & 5,427 & 5,016 \\
$\begin{array}{l}\text { Feed price at finisher } \\
\text { period (IDR) }\end{array}$ & 6,572 & 5,855 & 5,309 & 4,761 \\
Revenue (IDR)/head & 46,360 & 53,400 & 51,920 & 54,040 \\
Feed cost (IDR)/head & 11,002 & 13,486 & 13,542 & 13,598 \\
IOFC (IDR)/head & 35,358 & 39,914 & 38,378 & 40,442 \\
\hline
\end{tabular}

Note: Treatment diets containing $0 \%(\mathrm{~T} 0), 6 \%$ (T1), $12 \%$ (T2), and $18 \%$ (T3) of Salvinia molesta leaf (SML). IOFC= income over feed cost.

Table 5. Investment analysis of kampong chickens fed diet with various levels of Salvinia molesta

\begin{tabular}{lrrrr}
\hline \multirow{2}{*}{ Items } & \multicolumn{4}{c}{ Treatment diets } \\
\cline { 2 - 5 } & \multicolumn{1}{c}{ T0 } & \multicolumn{1}{c}{ T1 } & \multicolumn{1}{c}{ T2 } & \multicolumn{1}{c}{ T3 } \\
\hline NPV & $134,296,000$ & $188,968,000$ & $171,016,000$ & $195,304,000$ \\
PP (month) & 1.37 & 1.08 & 1.16 & 1.06 \\
B/C Ratio & 2.92 & 3.70 & 3.44 & 3.79 \\
\hline
\end{tabular}

Note: Treatment diets containing $0 \%$ (T0), 6\% (T1), 12\% (T2), and 18\% (T3) of Salvinia molesta leaf (SML). NPV= net present value; $\mathrm{PP}=$ payback period; $\mathrm{B} / \mathrm{C}$ Ratio= benefit-cost ratio.

consumption. This finding is in line with the report of Santoso et al. (2017), stating that SML has good palatability so that it will increase feed consumption. The final weight has a high correlation with feed consumption. Increasing feed consumption will increase the final weight. Therefore, the increasing level of SML in the feed will also increase the final weight of the Kampong chickens. In this study, there was no mortality found during the experiment, so we conclude that SML supplementation in the ration does not have a deleterious effect (Santoso et al., 2017; Moozhiyil \& Pallauf, 1986).

The utilization of $S$. molesta in the ration of Kampong chicken increased body weight and FCR. These results are supported by the findings of Dwiloka et al. (2015), Moozhiyil \& Pallauf (1986), Gini \& Jothi (2018), and Brouwer (2019) that argue that SML as an aquatic plant contains high fiber and tannin which will increase nutrient utilization and ultimately lead to a poor FCR, but with a better weight in duck performance. Even though the FCR is increased by the use of S. molesta, breast muscle and abdominal fat are also getting higher.

The feed price in the starter and finisher periods for Kampong chickens fed ration with SML percentage of

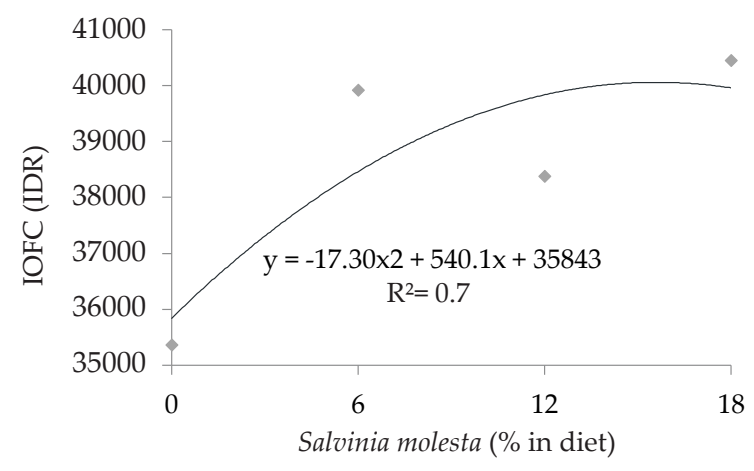

Figure 5. Income over feed cost (IOFC) of kampong chicken fed diet with various levels of Salvinia molesta leaf (SML)

$18 \%$ (T3) are at the lowest price compared with rations with SML concentrations of $0 \%$ (T0), $6 \%$ (T1), and 12\% (T2), which means that the feed price decreases when the proportion of SML increases in the feed. The feed cost of ration with SML concentration of $18 \%$ (T3) is the highest compared with the other feeds. The increased feed cost in Kampong chickens fed ration with SML concentration of $18 \%$ (T3) is related to the increased feed intake. However, the final body weight of Kampong Chickens fed ration with SML content of $18 \%$ (T3) was the highest. The highest final body weight leads to an increase in revenue and finally gives the best income (Omasaki, 2017).

Investment in 1000 heads of Kampong chickens fed ration supplemented with $S$. molesta is also feasible. Even though the use of SML increased feed cost, the revenue also increased with the use of SML in the ration. Because the increase in revenue is higher than the increase in feed cost, the income also increases. An

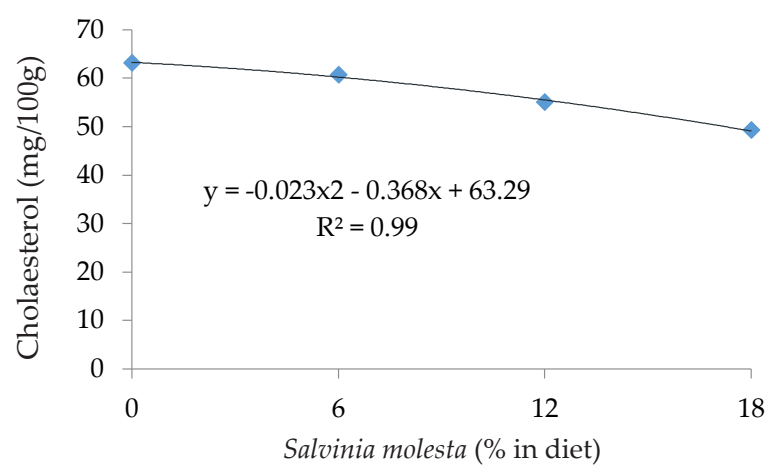

Figure 6. Meat cholesterol concentrations of kampong chicken fed diet with various levels of Salvinia molesta leaf (SML)

Table 6. Meat cholesterol, HDL, and LDL contents of kampong chickens fed diet with various levels of Salvinia molesta

\begin{tabular}{llcccc}
\hline \multirow{2}{*}{ Items } & \multicolumn{4}{c}{ Treatment diets } & \multirow{2}{*}{ P-value } \\
\cline { 2 - 5 } & \multicolumn{1}{c}{ T0 } & T1 & T2 & T3 & \\
\hline Cholesterol (mg/100 g) & $63.15 \pm 0.903^{\mathrm{a}}$ & $60.67 \pm 1.47^{\mathrm{b}}$ & $55.09 \pm 1.36^{\mathrm{c}}$ & $49.25 \pm 1.34^{\mathrm{d}}$ & $<0.01$ \\
HDL (mg/100 g) & $17.95 \pm 1.02^{\mathrm{a}}$ & $16.86 \pm 0.817^{\mathrm{a}}$ & $20.57 \pm 0.93^{\mathrm{b}}$ & $21.41 \pm 0.45^{\mathrm{b}}$ & $<0.01$ \\
LDL (mg/100 g) & $45.20 \pm 0.49^{\mathrm{a}}$ & $43.80 \pm 0.714^{\mathrm{b}}$ & $37.30 \pm 0.65^{\mathrm{c}}$ & $33.56 \pm 0.86^{\mathrm{d}}$ & $<0.01$ \\
\hline
\end{tabular}

Note: means in the same row with different superscripts differ significantly (p<0.05). Treatment diets containing $0 \%(\mathrm{~T} 0), 6 \%$ (T1), $12 \%(\mathrm{~T} 2)$, and $18 \%$ (T3) of Salvinia molesta leaf (SML). NPV= net present value; $\mathrm{PP}=$ payback period; $\mathrm{B} / \mathrm{C}$ Ratio= benefit-cost ratio. 
increase in income leads to a better NPV, B/C ratio, and payback period. Kampong chickens fed ration with SML concentration of $18 \%$ (T3) give the best NPV, B/C ratio, and PP compared to the other Kampong chickens fed rations with SML concentrations of $0 \%$ (T0), 6\% (T1), and $12 \%$ (T2). Investment on 1000 heads of Kampong chicken business fed by SML meal on a diet up to $18 \%$ gives the best feasibility.

S. molesta decreases the levels of cholesterol and LDL significantly, while the HDL increases with the increasing use of S. molesta (Figure 6). It can be concluded that the SML meal at the concentration of $18 \%$ (T3) gives the best result on cholesterol, HDL and LDL. Cholesterol is a complex fat compound that is contained in the cells of the body, especially in the cell surface and intracellular membrane (Rini et al., 2014; Setyadi et al., 2013). Cholesterol is derived from food and plays an important role as the main sterol in the body. Consumption of foods that are high in fat and cholesterol will increase total cholesterol levels and LDL levels that can trigger various diseases (Sastromidjodjo, 2000). Therefore, although Kampong chicken has already been famous for its low cholesterol, this utilization of S. molesta still can be an attraction to increase demand because health consciousness is one of the consumer's drivers. Consumers are now very concerned about issues of calorific content, pesticides, organics, additives, and salt/sugar level (McClements, 2019).

The increasing level of SML will suppress the cholesterol level in the meat. In line with the report of Dwiloka et al. (2015) that SML supplementation has been proven to suppress the cholesterol level of meat to the ideal ratio between LDL and HDL levels. The high fiber content in SML decreases the cholesterol content of duck meat. The utilization of SML in Kampong chicken diet will decrease the cholesterol of kampong chicken meat, reducing the cholesterol contents of the meat that will increase the meat quality, and finally will increase the meat price. In addition, the utilization of SML in Kampong chickens significantly reduces low density lipoprotein (LDL) and increases high density lipoprotein (HDL). This result is in line with the results reported by Al-Rekabi et al. (2020), Aderemi et al. (2018), and Mishra et al. (2016) in which the substitution of the aquatic plant instead of soybean meal can lead to the improved some of the biochemical blood traits for chicken. Further research is necessary to determine the quality of Kampong Chicken meat by incorporating SML leaf in the diet.

\section{CONCLUSION}

Incorporating SML up to $18 \%$ in Kampong Chicken diet yielded the best economic performance for Kampong Chicken rearing system. Cholesterol differed statistically amongst the treatments. However, the utilization of SML $(18 \%)$ in the diet could reduce the concentration of LDL and increase the concentration of (HDL).

\section{CONFLICT OF INTEREST}

We certify that there is no conflict of interest with any financial, personal, or other relationships with other people or organization related to the material discussed in the manuscript.

\section{REFERENCES}

Aderemi F. A., O. M. Alabi, M. Agbaje, A. G. Adeleke, \& M. O. Ayoola. 2018. Utilization of duckweed meal as replacement for fish meal by broiler chickens. Insight Poultry Research 8:1-9.

Akpaeti, A. \& D. Agom. 2018. Comparative cost analysis of broiler chicken fedwith concentrate and Aspilia africana. Asian Journal of Advances in Agricultural Research 6:1-7. https://doi.org/10.9734/AJAAR/2018/36202

Al-Rekabi, M. M, N. A. L. Ali, \& F. R. Abbas. 2020. Effect of partial and total substitution for azolla plant (Azolla pinnata) powder instead of soybean meal in broiler chickens diets on blood biochemical traits. Plant Arch. 20:1344-1348.

Amerah, A. M., A. Quiles, P. Medel, J. Sanchez, M. J. Lehtinen, \& M. I. Gracia. 2013. Effect of pelleting temperature and probiotic supplementation on growth performance and immune function of Kampongs fed maize/soy-based diets. Anim. Feed Sci. Technol. 180:55-63. https://doi. org/10.1016/j.anifeedsci.2013.01.002

Anderson, K. E. Z., A. M. Stomp, \& J. Chang. 2011. Duckweed as a feed ingredient in laying hen dietsand its effect on egg production and composition. Int. J. Poult. Sci. 10: 4-7. https://doi.org/10.3923/ijps.2011.4.7

Brouwer, P., K. G. J. Nieropb, W. J. J. Huijgenc, \& H. Schluepmann. 2019. Aquatic weeds as novel protein sources: Alkaline extraction of tannin-rich Azolla. Biotechnol. Rep. 24:324-337. https://doi.org/10.1016/j.btre.2019.e00368

Chander Y. D., B. D. Singh, S.Vishal, \& S. Subhasish. 2017. Effect of aloe vera (Aloe barbadensis) supplementation on production indices, mortality and cost of production of broiler chicken. J. Anim. Rsc. 7:107-113. https://doi. org/10.5958/2277-940X.2017.00015.8

Dwiloka, B., A. Setiadi., S. I. Santoso., E. Suprijatna, \& S. Susanti. 2015. Effects of duck feed supplemented with invasive giant salvinia (Salvinia molesta) on duck meat characteristics. Turk. J. Vet. Anim. Sci. 39: 68-675. https://doi. org/10.3906/vet-1411-52

FAO. 2010. Poultry Meat and Eggs: Agribusiness Handbook. Director of InvestmentCentre Division, FAO., Rome, Italy.

Gena, F., L. D. Mahfudz, \& Sumarsono. 2014. Utilizing Salvinia molesta as alternative protein source in broiler diet and the effect on performance, breast muscle and abdominal fat. IOSR J. Agric. Vet. Sci. 7: 46-52. https://doi. org/10.9790/2380-07744652

Gini, T. G. \& G. J. Jothi. 2018. Column chromatography and HPLC analysis of phenolic compounds in the fractions of Salvinia molesta Mitchell. Egyptian Journal of Basic and Applied Sciences 5:197-203. https://doi.org/10.1016/j. ejbas.2018.05.010

Leterme, P., A. M. Londono, J. E. Munoz, J. Suarez, C. A. Bedoya, W. B. Souffrant, \& A. Buldgen. 2009. Nutritional value of aquatic ferns (Azolla filiculoides Lam. and Salvinia molesta Mitchell) in pigs. Anim. Feed Sci. Technol. 149:135148. https://doi.org/10.1016/j.anifeedsci.2008.04.013

Leterme, P., A. M. Londono, D. C. Ordonez, A. Rosales, F. Estrada, J. Bindelle, \& A. Buldgen. 2010. Nutritional value and intake of aquatic ferns (Azolla filicuides Lam. And Salvinia molesta Mitchell.) in sows. Anim. Feed Sci. Technol. 155:55-64. https://doi.org/10.1016/j.anifeedsci.2009.10.002

McClements, D. J. 2019. The Science of Foods: Designing Our Edible Future. In: Future Foods. Copernicus, Cham. https://doi.org/10.1007/978-3-030-12995-8

Mukherjee, A. K., P. Kalita, B. G. Unni, S. B. Wann, D. Saikia, \& P. K. Mukhopadhyay. 2010. Fatty acid composition of four potential aquatic weeds and their possible use as 
fish-feed neutraticals. Food Chem. 123: 1252-1252. https:// doi.org/10.1016/j.foodchem.2010.05.057

Mishra, D. B., D. Roy, V. Kumar, A. Bhattacharyya, M. Kumar, R. Kushwaha, \& S. Vaswani. 2016. Effect of feeding different levels of Azolla pinnata onblood bio-chemicals, hematology and immunocompetence traits of Chabro chicken. Vet. World. 9:192-198. https://doi.org/10.14202/ vetworld.2016.192-198

Moozhiyil, M. \& J. Pallauf. 1986. Chemical composition of the water fern, Salvinia molesta, and its potential as feed source for ruminants. Econ. Bot. 40:375-383. https://doi. org/10.1007/BF02858995

Nampoothiri, V. M. 2017. Aquatic plants and marine waste as animal feed. Sch. J. Agric. Vet. Sci. 4:249-254

Omasaki, S. K., K. Janssena, M. Bessonac, \& H. Komena. 2017. Economic values of growth rate, feed intake, feed conversion ratio, mortality and uniformity for Nile tilapia. Aquaculture 481:124-132. https://doi.org/10.1016/j. aquaculture.2017.04.013

Paguia, P. M., R. Q. Paguia, C. Balba, \& R. C. Flores. 2014. Utilization and evaluation of Moringa Oleifera L. as poultry feeds. APCBEE Procedia. 8:343-347. https://doi. org/10.1016/j.apcbee.2014.03.051

Rathod, K. D., D. D. Mohale, S. D. Gadekar, \& K.U. Bidwe. 2019. Effect of different herbal feed additives on feed efficiency in broilers. Int. J. Veterinary Sci. Anim. Husb. 4:24-26.

Rawat, D., R. Shah, D. B. Nepali, \& J. L. Yadav. 2018. Effect of homeopathic medicine (alfalfa), methionine and lysine supplementation in low protein based diets on the performance of broiler chicken. Int. J. Appl. Sci. Biotechnol. 6:174-180. https://doi.org/10.3126/ijasbt.v6i2.20432

Reyes, F. C. C., A. T. A. Aguirre, E. M. Agbisit Jr, F. E. Merca, G. L. Manulat, \& A. A. Angeles. 2018. Growth performances and carcass characteristics of broiler chickens fed akasya (Samanea saman (jacq.) merr.) pod meal. Trop. Anim. Sci. J. 41:46-52. https://doi.org/10.5398/tasj.2018.41.1.46

Rini, T.P., K. Darwin, \& N. Riri. 2014. Ilustration of cholesterol levels patients who get cupping therapy. JOM PSIK 1: 180-187.

Santoso, S. I. \& A. Setiadi. 2016. Profitable utilization of giant salvinia, Salvinia molesta, as local duck feed. Int. J. Poult. Sci. 15:121-125. https://doi.org/10.3923/ijps.2016.121.125

Santoso, S. I., S. Susanti, \& A. Setiadi. 2017. Economic analysis of male broiler chickens fed diets supplemented with Salvinia molesta. Int. J. Poult. Sci. 16:233-237. https://doi. org/10.3923/ijps.2017.233.237

Sastromidjodjo. 2000. Handbook of Patient Nutrition Management. Binarupa Askara, Jakarta

Setyadi, F., V.D.Y.B. Ismadi, \& I. Mangisah. 2013. Cholesterol levels, HDL and blood LDL due to the combination of lighting lengths and different feeding provisions in broiler chickens. Animal Agriculture Journal 2: 68-76.

SNI (Indonesian National Standard). 2017. Feed Poultry. Ministry of Agriculture, Indonesia.

Sudhakar, D., D. Morup, \& S. P. Kumar. 2016. Economics of small broiler units in jammu district of jammu and kashmir state. J. Anim. Rsc. 6: 157-165. https://doi. org/10.5958/2277-940X.2016.00026.7 